Fanil Gabdrafikov

Professor, Bashkir State Agrarian University, Ufa

Russian Federation

Marsel Abrarov

Assistant Professor, Bashkir State Agrarian University, Ufa

Russian Federation

Sergey Shamukaiev Assistant Professor, Bashkir State Agrarian University, Ufa

Russian Federation.

Irshat Aysuvakov

Engineer, Bashkir State Agrarian

University, Ufa

Russian Federation

Denis Kharisov

Senior Lecturer, Bashkir State Agrarian

University, Ufa

Russian Federation

Ural Makhiyanov

Senior Lecturer, Bashkir State Agrarian

University, Ufa

Russian Federation

Dmitriy Yukhin

Assistant Professor, Bashkir State Agrarian

University, Ufa

Russian Federation

\section{Theoretical and Experimental Study of a Hydraulically Actuated Diesel Pump- Injector Unit with Electronically Controlled Ring Valve}

The relevance of this study is subject to the fact that the intricate design of the valve assembly's control system shows the insufficiently highperformance characteristics of the pump-injector units. The purpose of the study is to develop a modernization model for a pump-injector unit to increase its functional performance and develop its control valve. The principal method to be used to investigate the problem is to assess the influence of the design parameters of the control valve on the quality of the operation of the pump-injector unit. The authors developed a method to upgrade a diesel pump-injector unit using a ring control valve, as well as a mathematical model for the operation of the ring control valve of the pump-injector unit, which allows for the establishment of parameters affecting the quality of its operation. Studies have shown the effectiveness of the control ring valve on the pump-injector unit. The ring valve performs the function of both the force and locking elements.

The absence in it of a particular power element (spring) can significantly reduce the volume of the intra-valve cavity. The ring functions as a freeedge mechanical multiplier built into it with a multiplication factor $\pi$. There is no spring, discharge volume decreases, and the pump-injector unit speed increases.

Keywords: pump-injector unit, electronically actuated valve, ring valve, valve stroke.

\section{INTRODUCTION}

In order to ensure the high technical and economic performance of automotive diesel engines in a wide range, it is necessary, first of all, to improve their fuel system in the direction of ensuring a quality fuel supply process in all possible modes of their operation.

The solution to the problem of improving fuel economy is facilitated by ensuring high pressures and fuel injection rates, which contribute to improving the atomization of the fuel and, on this basis, more rapid and complete combustion.

The problem of increasing the injection pressure is presented in papers by Qain et al. (2016), by means of changing the valve mechanism in the discharge line; the paper by Tao Qiu et al. (2015) offers the same by means of optimizing the cam mechanism, and the papers by Gabdrafikov and Sharifullin (2012) propose amending the cam filing law of the profile.

Parameters affecting the injection process with the development of a mathematical model are given in the papers by Miloljub (2017).

The new method of forcing fuel injection for small diesel engines is considered by scientists Salykin, Lipilin, and Skorobogatov (2017).

Received: January 2019, Accepted: March 2019

Correspondence to: Prof. Fanil Gabdrafikov, Depart. of

Heat and Power Engineering, Bashkir State Agrarian

University, Ufa, Russian Federation,

E-mail: fanil.gabdrafikov@bk.ru

doi: $10.5937 /$ fmet1903576G

(C) Faculty of Mechanical Engineering, Belgrade. All rights reserved
Designing new fuel systems with an electronically controlled battery capable of creating pressures up to $200 \mathrm{MPa}$ is presented in papers by Grekhov (2011).

Leading international manufacturers of fuel equipment (Bosch, Lucas, Denso, Zexel, Delphi, and others) are developing new fuel supply systems that provide maximum injection pressure of 160-170 MPa and even up to $200 \mathrm{MPa}$, preferring systems with pumpinjector units.

Pump (plunger) and injection (sprayer and its needle) elements are arranged in a single pump-injector unit. The absence of a long pipe can significantly increase the pressure of the injected fuel (the fineness of its spraying).

The increased interest in pump-injector units is explained by the complete correspondence to the two most important trends in the improvement of fuel supply equipment: injection intensification and compliance with steadily tightening environmental requirements. The benefits of pump-injector units are well-known: increase of injection pressure due to minimization of volumes of compressible fuel, the absence of injection, reduction of parts range, the abrupt cutoff of supply, less coking and long spray time, and lower power consumption.

Improvement of pump-injector units is currently proceeding along the path of using high-speed electromagnetic valves operated by an electronic unit for fuel metering while maintaining or utilizing some modification of, the traditional pump section with a mechanically driven plunger. 
Pump-injector units of original PT (pressure - time, meaning injection under pressure in a short period) fuel supply system by Cummins (USA) was used on some models of automotive diesel engines by Cummins (USA) and Detroit Diesel (USA).

The fuel enters the pump-injector unit through a jet under low pressure created by the booster pump. The amount of injected fuel is regulated by changing its pressure (throttling) before entering the pump-injector unit with the help of pilot valve assemblies controlled by the operator either directly or through a regulator.

Injection pressure reaches $140 \mathrm{MPa}$. The fuel cycle and injection start points depend on the load and crankshaft rotational speed.

Bosch has developed a series of pump-injector units with valve-controlled fuel supply and injection phases. They are designed for diesel engines with a working volume of $1 \ldots 21$ each.

The PDE pump-injector unit plunger does not have spiral cut-off edges and axial fixation. It is driven by a cam mounted on a diesel camshaft. When the poppet valve is opened, and the plunger is in the upper position, the fuel fills the sub-plunger cavity. After the valve is closed, the plunger forces fuel to the closed-type nebulizer and the plunger injects it into the combustion chamber.

Detroit Diesel (USA), which traditionally uses a model DDA pump-injector unit with a mechanically driven plunger and flow control using an oblique cut-off edge on the plunger and a rack and pinion mechanism controlled by a cumbersome mechanical regulator, manufactures in series the DDEC pump-injector unit with valve control fuel supply and injection phases, and an electronic regulator since 1985. The design of the DDEC pump-injector unit is in many respects similar to the PDE pump-injector unit by Bosch. It is installed on 6V-92T six-cylinder diesel engines.

Lucas CAV (United Kingdom), in collaboration with AVL (Austria), developed a standard valve-controlled EUI-pump-injector unit range, providing injection pressure of $100-150 \mathrm{MPa}$ and intended for diesel engines with a cylinder capacity from 0.4 to 2.2 liters.

In recent years, Cummins (USA) has manufactured for injection of multi-cylinder diesel engines of its production PT pump-injector unit with a mechanically driven plunger, an open type sprayer, and fuel metering by inlet throttling (pressure-time principle). Also, the company has developed (based on PT pump-injector units) two new systems with electronic control.

The requirements for fuel efficiency and exhaust emissions of automotive engines, toughened in recent years, stimulate the search for new technical solutions.

A high-pressure pump-injector unit with a highspeed electro-controlled DDEC valve by Detroit Diesel Allison (USA) is considered to be promising.

Analysis of the literature data of scientific works of international companies like Caterpillar, Bosch, and Cummins shows that the most promising fuel systems are those with electronically controlled pump-injector units (HEUI - Hydraulically Actuated Electronically Controlled Unit Injection), as they combine the features of separate and battery systems. Compared to common rail type battery systems, the HEUI system consumes less power to create high pressure.

In order to increase the valve performance, the modernization of the solenoid pump-injector unit was performed by Song Jun et al. (2008).

Xuan-Thien Tran et al. (2003) presented a simulation of the injection process by the HEUI fuel injection system in MatLab Simulink.

There are researches to develop a method for diagnosing the pump-injector units of the HEUI system (Edwin Puente, 2018).

The use of the HEUI injection system on two-stroke engines is provided in work by Zhang et al. (2016).

There are researches on the modernization of the drive and valve assembly of the HEUI pump-injector units (by Edward G. Maines [US] and Elan R. Stockner [US]).

Mathematical modeling of HEUI pump-injector unit operation in unsteady modes is given in the works by Jui-Jung Liu et al.

The analysis of published scientific works shows that the latter is mainly devoted to the problems of diagnostics and improvement of the pump-injector unit control system.

Issues of improving pump-injector units and identifying the flaws in their assemblies are presented in the works by Coldren, Schuricht, and Smith (2003).

The HEUI fuel supply system improves fuel efficiency, but it still does not have sufficiently high operational reliability and increase the cost of the fuel injection system.

One of the drawbacks in the HEUI pump-injector unit design is the need to use a control valve with a large flow area and a return spring, which increases the amount of the valve surface and, as a result, affects the increase in valve's response time and current consumption.

The purpose and objective of the study are to develop a model of the pump-injector unit modernization to improve the quality of the pumpinjector work along with the development of a control valve. The main task is to modernize the pump-injector unit based on the use of the split elastic ring, which allows for obtaining the speed control valve.

\section{MATERIALS AND METHODS}

The authors have developed a method of upgrading the HEUI pump-injector unit system (with a complex system of the pressure regulator of the plunger hydraulic drive) by a significant simplification of the valve assembly.

A developed split elastic ring with electronic control was used as a control valve. Figure 1 shows the upgraded pump-injector unit with electronically controlled ring valve.

Pump-injector unit works as follows. The electronic control unit based on the input signals from various electronic sensors at a particular moment supplies current to the electromagnet 3 . It creates a magnetic force that attracts the ring valve 2. At this point, the channel A and the over piston cavity B are combined, while the free end of the ring valve 2 is additionally 
moving by $\pi \cdot h$ (h - valve lift height) through the seat in the housing 1 closes the discharge channel $\mathrm{C}$. The fluid from the pump goes under pressure to the upper part of the injection piston 5. Fluid pressure moves the injection piston 5 and, accordingly, the plunger 6 downwards, thereby injecting occurs.

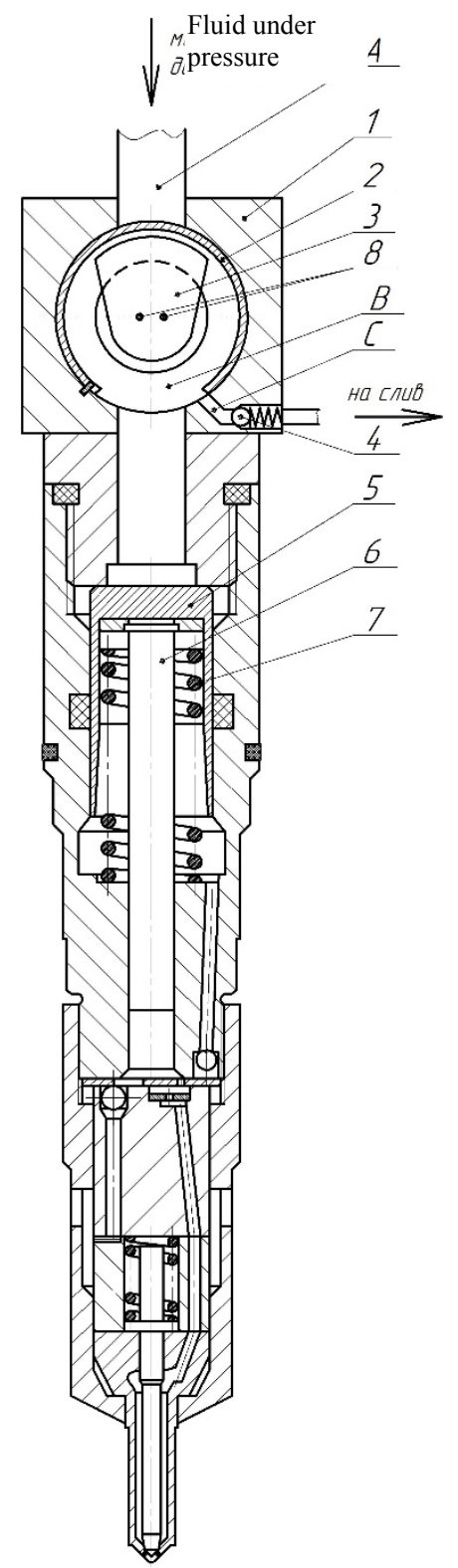

Figure 1. Modernized pump-injector unit with the hydraulically actuated plunger and electronically controlled ring valve: 1 - valve body; 2 - ring valve; 3 - electromagnet; 4 drain valve; 5 - pressure piston; 6 - plunger; 7 - spring; 8 conductors.

Injection is completed by switching off the current supplied from the electronic unit. The ring valve 2 under its elasticity returns to its original position by blocking channel A and connecting cavity B to discharge channel C. Due to the spring 7 elasticity, the pressure piston 5 returns to its initial position, and the fluid goes to the discharge.

The ring valve 2 is held in the seat by its elasticity and residual fluid pressure, and therefore also can function without electronic control due to the hydraulic drive.

One of the most important indicators of the control ring valve's operation, which defines the features of its design for the studied case, is the height (stroke) of the ring $\mathrm{h}$ (Figure 2) in the area of the fluid supply channel (oil) opening seal in the process of filling the control valve's internal valve cavity.

Reliability of operation and speed of the hydraulically actuated plunger of the pump-injector unit with a ring control valve is determined by the tightness (stroke) of the overlap of the free channel ring of the drain channel $\mathrm{C}$ depending on the valve stroke. In this regard, the optimal dimensions of the ring valve should be determined by ensuring the tightness of the overlap with its free edge of channel $C$, i.e., its stroke is equal $\pi \cdot h$. Therefore, identifying optimal design parameters, which determine the stroke $h$ of the ring valve, are interesting. The model of the valve ring operation is shown in Figure 2.

In order to justify the design parameters of the ring valve, let us consider the equation of the balance of forces acting on it (Figure 2):

$$
p_{\mathrm{rad}} \cdot b \cdot D=P_{s t}+P_{h}
$$

or

$$
c \sigma=\Delta p f_{k}+Q \rho\left(v_{1}-v_{2} \cos \beta\right),
$$

where $p_{\text {rad }}$ is radial pressure of the ring on the seat wall;

$b, D$ are the ring valve width and diameter, respectively;

$P_{s t}$ is static fluid pressure;

$P_{h}$ is the hydrodynamic force (flow response to the valve);

$c$ is ring rigidity;

$\sigma$ is the difference between the diameters of the ring (before its cut) and the valve seat;

$\Delta p=p_{1}-p_{0}$ is differential pressure up to $\left(p_{1}\right)$ and after $\left(p_{0}\right)$ valve;

$f_{k}=\pi \cdot d_{k}^{2} / 4$ is a cross-sectional area of the injection channel;

$d_{k}$ is the fluid supply channel diameter;

$Q$ is fluid consumption per second;

$\rho$ is fluid density;

$v_{1}, v_{2}$ are average fluid velocity in front of the valve and its gap;

$\beta$ is the angle of fuel flow direction (for the case of $D \leq d_{k}, \beta=90^{\circ}$ is allowed).

For a relatively small ring lift, it is quite acceptable to assume that the fuel flow is laminar between the ring and valve seat. Thus, it is possible to use the known equations of energy and continuity of flow for the calculation.

For the considered case (when the fuel flow area is determined by the fuel supply channel diameter, the ring width, and the distance between the notches in the socket $\mathrm{d} 0$ ), the fluid flow between the flat discs can be considered radial and the sealing zone of the ring can be regarded as a round flat valve (i.e., shaded areas $f$ shall be neglected, Figure 2).

In order to calculate the velocities and pressures in the laminar fluid flow between flat disks (in this case, the sealing zone between the ring and the valve seat), the authors use the Navier-Stokes equation. 


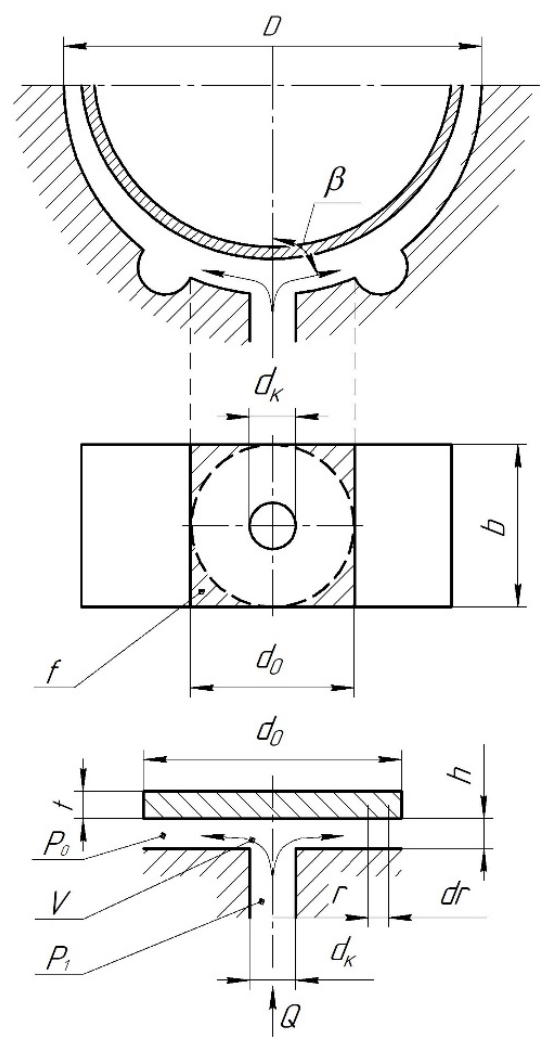

Figure 2. Ring valve function model: $h$ is valve stroke; $t$ is the ring valve width; $\mathrm{d} 0$ is the distance between the seat grooves (valve working area diameter) $r$ is the valve working area radius.

The equation of motion is a mathematical expression of the equilibrium of all forces applied to an element of fluid and under the condition of continuity of variables; it can be expressed in a vector form:

$$
\frac{\partial v}{\partial \tau}+v(\operatorname{grad} v)=v(\operatorname{div} \operatorname{grad} v)-\frac{1}{\rho} \operatorname{grad} p
$$

The energy equation expresses the energy conservation law:

$$
\frac{\partial T}{\partial \tau}+v(\nabla T)=\alpha(\operatorname{div} \operatorname{grad} T)-\frac{1}{v c} \frac{d \Phi}{d \tau}
$$
law:

The equation of continuity is the mass conservation

$$
\operatorname{div} v=0
$$

where $\frac{\partial v}{\partial \tau}$ is the local component of acceleration (considers the unsteady nature of the flow);

$v(\operatorname{grad} v)$ is convective acceleration component (considers the movement of fluid particles);

$v(\operatorname{div} \operatorname{grad} v)$ considers the fluid viscosity;

$\frac{1}{\rho} \operatorname{grad} p$ considers pressure;

$\frac{\partial T}{\partial \tau}$ is the local change in fluid temperature;

$v(\nabla T)$ considers convective heat transfer;

$\alpha(\operatorname{div} \operatorname{grad} T)$ considers the heat transferred by thermal conductivity; $\frac{1}{v c} \frac{d \Phi}{d \tau}$ considers heat generated by internal sources.

In order to calculate the velocities and pressures, in this case, the Navier-Stokes system of equations will then be written in a cylindrical coordinate system:

$$
\begin{gathered}
\frac{\partial v_{r}}{\partial \tau}+v_{r} \frac{\partial v_{r}}{\partial r}+\frac{v_{\varphi}}{r} \frac{\partial v_{r}}{\partial \varphi}+v_{z} \frac{\partial v_{r}}{\partial z}-\frac{v_{\varphi}^{2}}{r}= \\
=v\left(\frac{\partial^{2} v_{r}}{\partial r^{2}}+\frac{1}{r^{2}} \frac{\partial^{2} v_{r}}{\partial \varphi^{2}}+\frac{\partial^{2} v_{r}}{\partial z^{2}}+\right. \\
\left.\frac{1}{r} \frac{\partial v_{r}}{\partial r}-\frac{2}{r^{2}} \frac{\partial v_{\varphi}}{\partial \varphi}-\frac{v_{r}}{r^{2}}\right)-\frac{1}{\rho} \frac{\partial p}{\partial r} \\
\frac{\partial v_{z}}{\partial \tau}+v_{r} \frac{\partial v_{z}}{\partial r}+\frac{v_{\varphi}}{r} \frac{\partial v_{z}}{\partial \varphi}+v_{z} \frac{\partial v_{z}}{\partial r}= \\
v\left(\frac{\partial^{2} v_{r}}{\partial r^{2}}+\frac{1}{r^{2}} \frac{\partial^{2} v_{z}}{\partial \varphi^{2}}+\frac{\partial^{2} v_{z}}{\partial z^{2}} \frac{1}{r} \frac{\partial v_{z}}{\partial r}\right)-\frac{1}{\rho} \frac{\partial p}{\partial z}
\end{gathered}
$$

where $v_{r}, v_{\varphi}, v_{z}$ are the - components of speed along the radius and circumference of the sealing surface of the ring, along with the $\mathrm{z}$-axis of the ring lift.

$\nu, \rho$ is kinematic viscosity and density of the fluid.

The system is complemented by the equation of continuity, which expresses the mass conservation law:

$$
\frac{\partial v_{r}}{\partial r}+\frac{1}{r} \frac{\partial v_{\varphi}}{\partial \varphi}+\frac{\partial v_{z}}{\partial z}+\frac{v_{r}}{r}=0
$$

Assuming that the temperature and viscosity of the fuel will be constant, the energy equations in the calculations will not be considered.

Let us simplify motion control (6 and 7) for the case under consideration by adopting the following:

$v_{z}=0$ (let us consider the open position of the valve);

$v_{\varphi}=0$ (fluid movement will be only along the radius);

Then equations (6), (7) and (8) for $v=$ const will look as follows:

$$
\begin{aligned}
& v \frac{\partial v_{r}}{\partial r}=v\left(\frac{\partial^{2} v_{r}}{\partial r^{2}}+\frac{\partial^{2} v_{r}}{\partial z^{2}}+\frac{1}{r} \frac{\partial v_{r}}{\partial r}-\frac{v_{r}}{r^{2}}\right)-\frac{1}{\rho} \frac{\partial p}{\partial r} \\
& \frac{\partial p}{\partial \varphi}=\frac{\partial p}{\partial z}=0 \\
& \frac{\partial v}{\partial r 0}+\frac{v_{r}}{r}=0
\end{aligned}
$$

Boundary conditions:

$z=0, v_{r}=0, v_{z}=0, z=h, v_{\varphi}=0, v_{r}=v(r, z)$.

From equation (11), the value $\frac{\partial^{2} v_{r}}{\partial r}$ is determined, and after its substitution into equation (9), the initial equation is obtained for determining the velocity and pressure between the ring and the valve seat in the sealing zone:

$$
\frac{\partial^{2} v_{r}}{\partial r^{2}}+\frac{1}{r} \frac{\partial v}{\partial r}-\frac{v}{r^{2}}=0
$$


Also, accepting that $v \frac{\partial v}{\partial r}$ is subsequently lower than $v\left(\frac{\partial^{2} v_{r}}{\partial z^{2}}\right)$, and considering the expression (12), let us get the equation (9) in the following form:

$$
\frac{1}{\rho} \frac{\partial p}{\partial r}=v\left(\frac{\partial^{2} v}{\partial z^{2}}\right)
$$

Integrating with respect to $\mathrm{z}$, let us find:

$$
v=\frac{1}{2 \rho v} \frac{\partial p}{\partial r} z^{2}+C_{1} z+C_{2}
$$

The boundary conditions, in this case, are at $v=0$ $z=0$ and $z=h$.

Given these conditions, the equation (14) takes the following form:

$$
v=\frac{1}{2 \mu} \frac{\partial p}{\partial r}\left(z^{2}-h z\right)
$$

where $\mu$ is dynamic viscosity of the fluid.

The fluid flow rate through this gap (between the ring and the seat) can be determined using the equation:

$$
Q=2 \pi r h v_{c p}
$$

where $v_{c p}=\frac{1}{h} \int_{0}^{h} v d z$.

Substituting the value of $v$ from the equation (15) and integrating it, the following is received:

$v_{c p}=\frac{1}{h} \int_{0}^{h} v d z=v=\frac{1}{2 \mu} \frac{\partial p}{\partial r} \frac{1}{h} \int_{0}^{h}\left(z^{2}-h z\right) d z=\frac{h^{2}}{12 \mu} \frac{\partial p}{\partial r}$

Substituting the values of $v_{c p}$ from equation (17) into expression (16), the following expression for determining the flow rate is obtained:

$$
Q=-\frac{\pi r h^{3}}{6 \mu} \frac{\partial p}{\partial r}
$$

The equation for fluid flow between disks for an infinitely small radial length $d r$ is as follows:

$$
\frac{\partial p}{\partial r}=-\frac{6 \mu Q}{\pi r h^{3}}
$$

Integrating the equation (19) with respect to the radius $r$, the following is received:

$$
p=-\frac{6 \mu Q}{\pi h^{3}} \ln r+C_{3}
$$

The integration constant value $\mathrm{C}_{3}$ and the flow rate $Q$ will be determined using the following boundary conditions:

Therefore

$$
C_{3}=p_{0}+\frac{6 \mu Q}{\pi h^{3}} \ln r_{0}
$$

Substituting expression (21) into equation (20), the following is received:

$$
p-p_{0}=\frac{6 \mu Q}{\pi h^{3}} \ln \frac{r_{0}}{r}
$$

At $r=r_{k}, p=p_{1}$ the equation (22) will take the following form:

$$
p_{1}-p_{0}=\frac{6 \mu Q}{\pi h^{3}} \ln \frac{r_{0}}{r_{k}} \text { or } \Delta p=\frac{6 \mu Q}{\pi h^{3}} \ln \frac{d_{0}}{d_{k}}
$$

For this case, the distance between the grooves of the ring seat $d_{0}$ is determined by the ring width $b$, i.e. $d_{0}$ $=b$, then the expression (23) takes the form of:

$$
\Delta p=\frac{6 \mu Q}{\pi h^{3}} \ln \frac{b}{d_{k}}
$$

whence the fluid consumption expression is received:

$$
Q=\frac{\Delta p \pi h^{3}}{6 \mu \ln \frac{b}{d_{k}}}
$$

The distribution of fuel pressure between the ring and the valve seat is found by integrating equation (18) taking into account the boundary conditions.

Since at $r=r_{0}, p=p_{0}$, then

$$
p_{0}=\frac{6 \mu Q}{\pi h^{3}} \ln \frac{r_{0}}{r}
$$

and at $r=r_{k}, p=p_{1}$, then, it is clear that

$$
p_{1}=\frac{6 \mu Q}{\pi h^{3}} \ln \frac{r_{0}}{r_{k}}
$$

The expression determines the pressure distribution law over the radius of the gap:

$$
p=\Delta p \frac{\ln \frac{r_{0}}{r}}{\ln \frac{r_{0}}{r_{k}}}
$$

In order to determine the pressure force $P_{h}$ on the ring (lifting the ring), the authors consider the elementary force, which is applied to the radius per length $\partial r$ :

$$
d P_{h}=2 \pi r p \partial r
$$

Then the following force is applied to the entire sealing surface of the ring:

$$
P_{h}=2 \pi \int_{0}^{\eta_{0}} p r \partial r
$$

Substituting expression (28) into (30) and integrating, let us find the hydrodynamic force $P_{h}$ : 


$$
\begin{aligned}
& P_{h}=2 \pi \int_{0}^{r_{0}} \Delta p r \frac{\ln \frac{r_{0}}{r}}{\ln \frac{r_{0}}{r_{k}}} \partial r=\frac{2 \pi \Delta p}{\ln \frac{r_{0}}{r_{k}}} \int_{0}^{r_{0}} \frac{r_{0}}{r} r \partial r= \\
& =\frac{2 \pi \Delta p}{\ln \frac{r_{0}}{r_{k}}} \int_{0}^{r_{0}} \frac{r_{0}}{r}\left(\ln r_{0}-\ln r\right) \partial r= \\
& =\frac{2 \pi \Delta p}{\ln \frac{r_{0}}{r_{k}}}\left[\ln r_{0} \int_{0}^{r_{0}} r \partial r-\int_{0}^{r} \ln r \partial r\right] \\
& \int_{0}^{r} r \ln r \partial r=\lim _{b \rightarrow 0+} \int_{0}^{r} \ln r \partial r=\lim _{b \rightarrow 0+}\left[\left.\frac{r^{2} \ln r}{2}\right|_{b} ^{b}-\frac{1}{2} \int_{b}^{r} \frac{r^{2}}{r} \partial r\right]= \\
& \lim _{b \rightarrow 0+}\left[\frac{r_{0}}{2} \ln r_{0}-\frac{b^{2}}{2} \ln b-\left.\frac{r^{2}}{4}\right|_{b} ^{r}\right]= \\
& =\lim _{b \rightarrow 0+}\left[\frac{r_{0}^{2}}{2} \ln r_{0}-\frac{r_{0}^{2}}{4}-\frac{b^{2}}{2} \ln b+\frac{b^{2}}{4}\right]=\frac{r_{0}^{2}}{2} \ln r_{0}-\frac{r_{0}^{2}}{4} \\
& P_{h}=\frac{2 \pi \Delta p}{\ln \frac{r_{0}}{r_{k}}}\left(\frac{r_{0}^{2}}{2} \ln r_{0}-\frac{r_{0}^{2}}{2} \ln r_{0}+\frac{r_{0}^{2}}{4}\right)=\frac{\pi \Delta p r_{0}^{2}}{2 \ln \frac{r_{0}}{r_{k}}}
\end{aligned}
$$

or

$$
P_{h}=\frac{\pi \Delta p d_{0}^{2}}{8 \ln \frac{d_{0}}{d_{k}}}
$$

Thus, the equation of balance of forces (2) after substitution of expression (32) is written in the following form:

$$
c \sigma=\Delta p \frac{\pi d_{k}^{2}}{4}+\frac{\pi \Delta p d_{0}^{2}}{8 \ln \frac{d_{0}}{d_{k}}}=\frac{\pi}{8} \Delta p\left(2 d_{k}^{2}+\frac{d_{0}^{2}}{\ln \frac{d_{0}}{d_{k}}}\right)
$$

If one considers that $d_{0}$ is determined by the width of the ring, i.e. $d_{0}=b$, and $\Delta p$ may be substituted with its value from the expression (28), then the equation (33) can be written in the following form:

$$
c \sigma=\frac{3 \mu Q}{4 h^{3}}\left(b^{2}+2 d_{k}^{2} \ln \frac{b}{d_{k}}\right)
$$

Hence, the valve stroke is as follows:

$$
h=\sqrt[3]{\frac{3 \mu Q\left(b^{2}+2 d_{k}^{2} \ln \frac{b}{d_{k}}\right)}{4 c \sigma}}
$$

From the expression (35) it follows that the valve stroke $\mathrm{h}$ depends on the discharge channel diameter $d_{k}$, the width $b$, diameter $D$, and the ring rigidity $c$, and fuel consumption per second $Q$.

The ring rigidity is found from the balance of forces of (1) and (2):

$$
c \sigma=p_{\text {rad }} b D
$$

and after substitution of $p_{\text {rad }}$ with its value for a ring with eccentric surfaces (curved bars of the variable section), it looks as follows:

$$
c=\frac{2 E t^{3} b}{3 D^{3}}
$$

where $\mathrm{E}$ is the modulus of elasticity of the ring material.

If the ring valve rigidity is substituted with its value (37) in the expression (35), then to determine the valve stroke, the following mathematical expression can be received:

$$
h=\frac{D}{2 t} \sqrt[3]{\frac{9 \mu Q\left(b+2 \frac{d_{k}^{2}}{b} \ln \frac{b}{d_{k}}\right)}{\sigma E}}
$$

Using this mathematical expression, the authors carried out theoretical studies in order to identify the optimal valve sizes. The following variables were used: ring rigidity (including diameter $\mathrm{D}$, width $\mathrm{b}$, valve thickness $t$, and fluid supply channel diameter $\mathrm{dk}$ ). The boundary conditions were determined from constructive considerations (A is boundary valve stroke parameter $\mathrm{A}=\mathrm{f}(\mathrm{D}, \mathrm{b}, \mathrm{t})$,$) . Individual block diagrams were developed$ for the calculations (Figure 3,4).

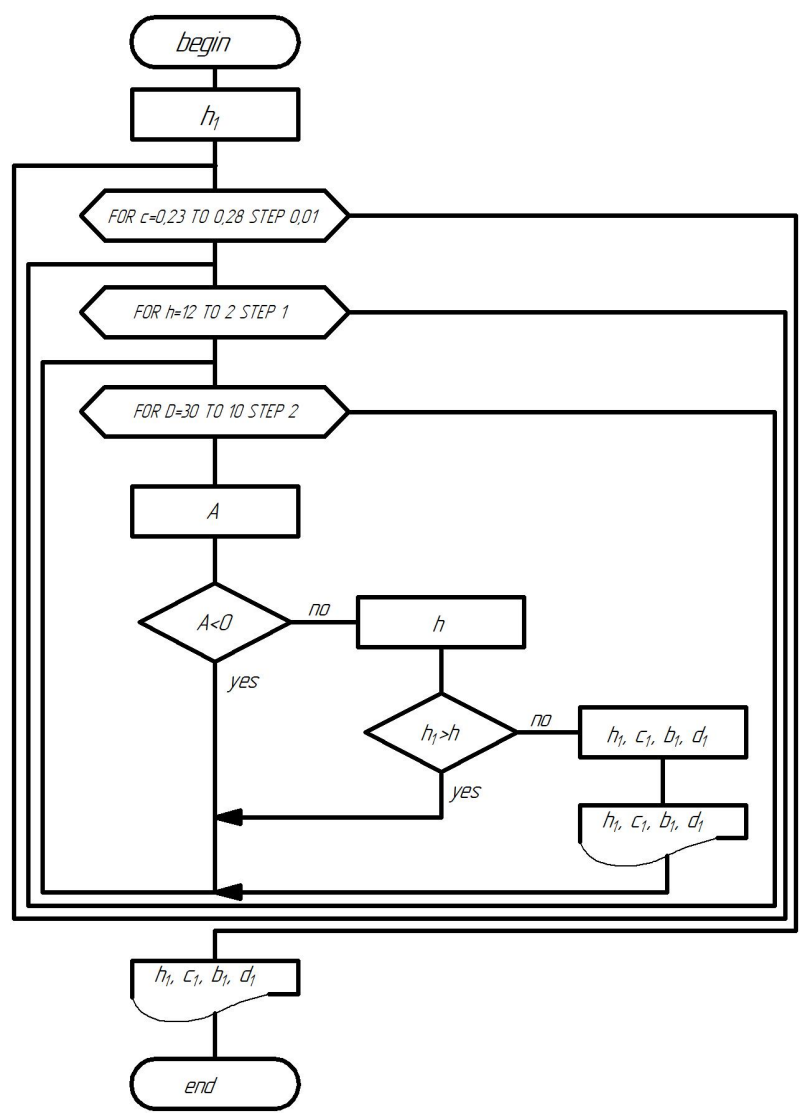

Figure 3. Block diagram for calculating the ring valve stroke

A particular device in the form of a fitting with interchangeable ring sockets and a displacement sensor (Figure 5) was previously manufactured for experimental studies of the ring valve stroke.

The device and the principle of operation are described in [9, pp. 101-113]. 


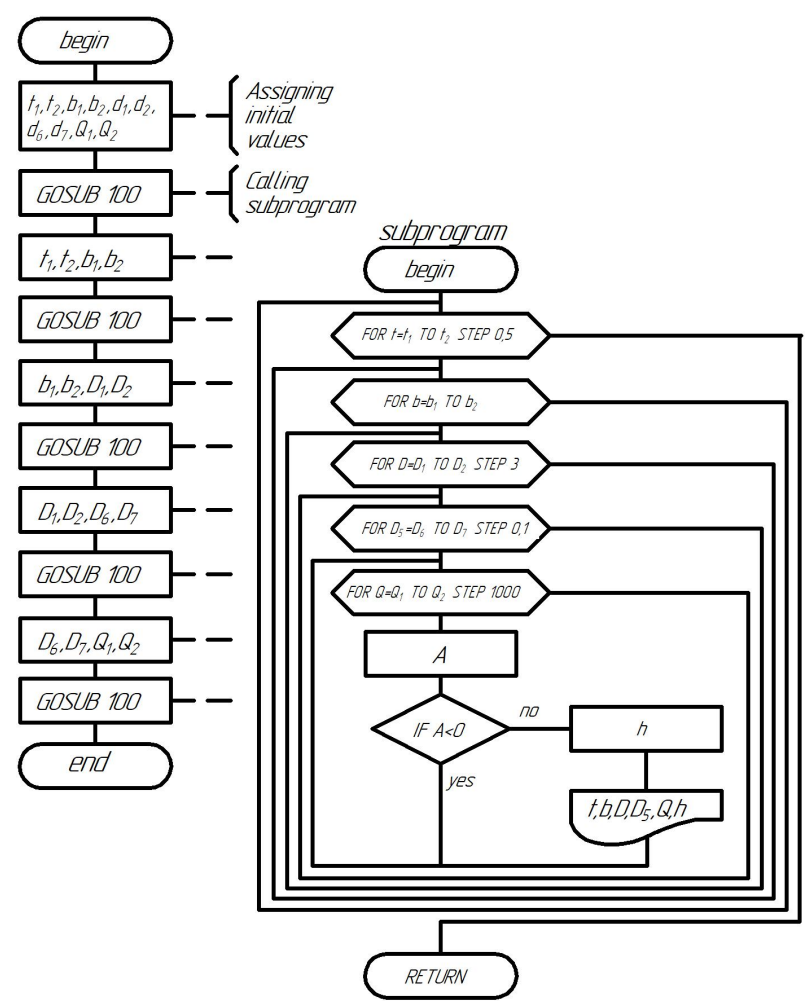

Figure 4. Block diagram of the program for calculating the optimal size of the ring valve

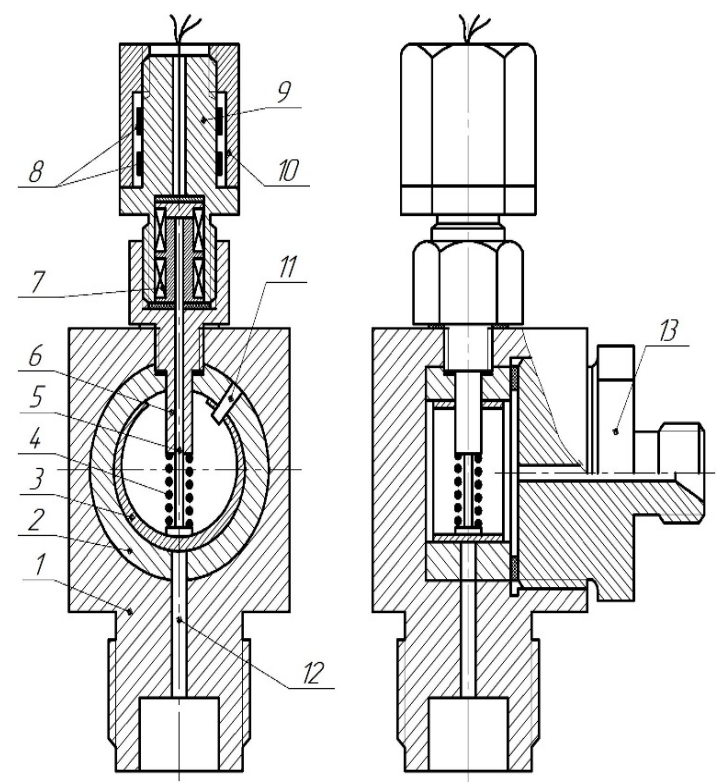

Figure 5. Experimental setup for testing the ring valve stroke: 1 - case; 2 - valve seat; 3 - valve; 4 - spring; 5 - rod; 6 - guide; 7 - coil; 8 - additional resistances; 9 - body coil; 10 - cap (screen); 11 - pin; 12 - discharge channel; 13 - fluid drain outlet

\section{RESULTS}

Based on the results of the calculation, a valve with a ring $\mathrm{t}<0.65 \mathrm{~mm}$ thick, a diameter of $20 \mathrm{~mm}$ and a width of $5 \mathrm{~mm}$ was chosen for the preliminary experimental studies. During the experiments, it appeared that sufficient rigidity was not ensured with such dimensions and this resulted in a high frequency of the pump shaft rotation, and the fact that the valve did not always have time to return to the seat, and the injection turned out to be unstable. Considering this circumstance rings $t \geq 0.65$ $\mathrm{mm}$ thick were used for further research. As expected, with a decrease in thickness and an increase in the ring diameter (i.e., with a decrease in its rigidity), the valve stroke increases.

The research results confirmed the consistency of the calculated and experimental data (Figure 6).

The discrepancy between the experimental and calculated data was initially at the ring width. This was explained by the fact that the experiments were carried out with a change in the width of the valve with a constant distance between the grooves of the socket (i.e., not considering that the main flow passes through the shortest distance). In this regard, the nature of the influence of the $b$ ring width was determined by the distance between the recesses of the seat in the sealing zone.

Repeated studies, provided that the distance between the grooves of the seat changed with a change in the ring width, confirmed the consistency of the calculated and experimental data and the valve width (curves 1 and 2 at Figure 6).

In the variant, when the condition $\mathrm{l}=\mathrm{b}$, adopted in the theoretical analysis, was maintained, its stroke increased with increasing ring width.

With an increase in the injection channel diameter $\mathrm{dk}$, the valve stroke also increased (due to an increase in the ring area, which perceives the force of fluid pressure).

From the calculated data (Figure 6) it follows that the largest stroke $(0.14 \mathrm{~mm})$ is obtained with a ring with a $20 \mathrm{~mm}$ diameter, $12 \mathrm{~mm}$ wide, $0.46 \mathrm{~mm}$ thick, and 3 mm supply channel.
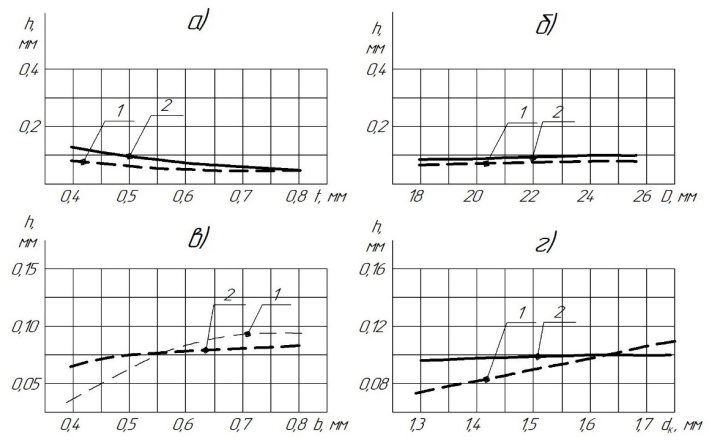

Figure 6. Dependence of the valve stroke on the thickness (a), the ring diameter (b), the width (c) and the supply channel diameter (d): 1 - experimental, 2 - calculated

Figure 7 shows the experimental (solid curves) and the corresponding calculated (dashed) valve stroke data for various cyclical fluid flows.

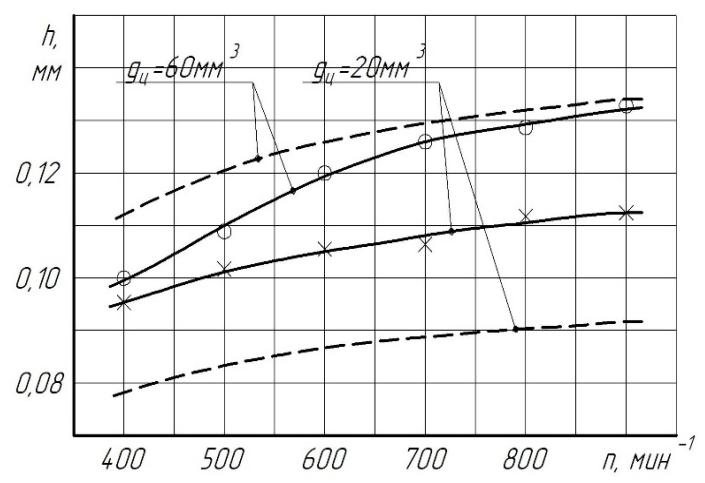

Figure 7 Experimental (solid) and calculated (dashed) dependences of the valve stroke on the shaft rotational speed (gh is cyclic fluid supply) 
As can be seen, there is no significant discrepancy between the calculated and experimental data, especially at high feed rates and relatively high shaft rotational frequencies.

A ring valve was manufactured with the specified dimensions and installed in the pump-injector unit with the possibility of electronic control for its stroke. In this case, the outer and inner diameters of the ring to the cut were $20 \mathrm{~mm}$ and $19.3 \mathrm{~mm}$, and the eccentricity between its outer and inner surfaces was $0.11 \mathrm{~mm}$.

A new technical effect is obtained - reducing the response time of the control valve with the above model of upgrading the hydraulically actuated pump-injector unit with ring control and electronic valve control with optimal ring parameters. This is achieved by the fact that the free edge of the split elastic ring, as a mechanical multiplier, closes the discharge channel $\pi$ times faster than the valve stroke when it rises from the pressure of a fluid flow or signal when the electromagnet is on. The ring valve also acts as a spring to return to its original position, simplifying the design as much as possible.

\section{DISCUSSION}

A mathematical model of the functioning for the control ring valve of the pump-injector unit has been developed. It is consistent with the classical mathematical model of laminar flow.

The research resulted in a new mathematical description, which is the dependence of the valve stroke on its design parameters and which allows for calculating its optimal dimensions.

Theoretical and experimental data quite accurately describe the pattern of the influence of structural dimensions and parameters of the ring valve on its stroke.

The upgraded pump-injector unit differs from the existing one in that instead of the controlling freefloating valve (ball) or movable disc with springs in the valve assembly, the control valve is installed in the form of a split elastic ring, one end of which is fixed rigidly and the other with the possibility of blocking the drain channel of the fluid the activated electromagnet (installed with a gap inside the ring) or (in its absence or malfunction) from the valve stroke due to the pressure of the supplied fluid. Despite the manufacturing technology developed by the authors, these valves have not yet been thoroughly investigated and, therefore, are not completely finalized.

\section{CONCLUSION}

A methodology has been developed for upgrading a hydraulically actuated pump-injector unit of the HEUI system plunger based on its use as a control valve, made in the form of a split elastic ring.

A model of the functioning for the control ring valve of the pump-injector unit has been developed.

A new mathematical expression has been obtained for calculating the valve stroke depending on the ring valve design parameters.

The optimal dimensions of the control ring valve (diameter $20 \mathrm{~mm}$, ring width $12 \mathrm{~mm}$, thickness 0.46 $\mathrm{mm}$, the diameter of the control fluid feed channel 3 $\mathrm{mm}$ ) of the pump-injector unit, affecting the quality of work, have been established.

The upgraded pump-injector unit allows for getting a new technical effect - reducing the response time of the control valve by providing faster bridging of the discharge channel in 3.14 times, acting as a mechanical multiplier, and, as a result, improving the system performance and fuel injection quality in a wide range of diesel operation.

Further research requires developing of a mathematical model of the fuel injection process of the pumpinjector unit with an electronically controlled ring valve. Also, research on the required power of the electromagnet with electronic control is needed.

\section{REFERENCES}

[1] Dexing, Qian, Ridong. Liao, Jianhua. Xiang, Baigang. Sun and Shangyong. Wang. FluidStructure Interaction Analysis on the Performance of the High-Pressure Fuel Pump for Diesel Engines. ASME 2016 International Mechanical Engineering Congress and Exposition. Phoenix, Arizona, USA, 2016.

[2] Qiu, Tao, Dai, Hefei, Lei, Yan, Cao, Chunlei and $\mathrm{Li}$, Xuchu. Optimizing the cam profile of an electronic unit pump for a heavy-duty diesel engine. Energy, Elsevier, Vol. 83(C), pp. 276-283. 2013.

[3] Štavljanin, M Mathematical modeling, and identification of the mathematical model parameters of diesel fuel injection systems, pp. 421441. Vojnotehnički Glasnik, Vol. 65, Issue 2, 2017.

[4] Salykin, E.A., Lipilin, V.I. and Skorobogatov, A.A. Method of Fuel Injection in Small Diesel Engines Author links open overlay panel, Procedia Engineering, Volume 206, pp. 1552-1557, 2017.

[5] Grekhov, L.V. Design of high-pressure fuel pumps for battery systems of diesel engines. Mechanical Engineering, Vol. 12, pp. 27-32, 2011.

[6] Peng, Liu, Liyun, Fan, Qaisar, Hayat, De, Xu, Xiuzhen, Ma and Enzhe, Song. Research on key factors and their interaction effects of the electromagnetic force of high-speed solenoid valve. Hindawi Publishing Corporation. The Scientific World Journal, Volume 2014.

[7] Krivtsov, S.N., Yakimov, L.V. and Ozornin, S.P. Numerical analysis and experimental studies on solenoid common rail diesel injector with the worn control valve. IOP Conf. Series: Materials Science and Engineering, Vol. 327, pp. 042057, 2018.

[8] Wenfu, Sun and Xiaoqin, Mo. Simulation of Solenoid Valve Characteristics of Electronically Controlled Fuel System for Diesel Engines. IOP Conf. Series: Materials Science and Engineering, Vol. 381, pp. 012065, 2018.

[9] Gabdrafikov, F.Z. Evaluation of the operational efficiency of the fuel systems of the tractor and combine diesel engines in partial load modes. St.Petersburg: SPGAU Publishing, 2004. 
[10] Gabdrafikov, F. Z., Abrarov, M.A. Upgraded pump-nozzle with the electronically controlled valve. Mechanization and electrification of agriculture, Vol. 6, pp. 21-22, 2010.

[11] Gabdrafikov, F. Z., Shamukaev, S.B., Gaisin, E.M. and Safina, R.R. Mathematical Description of the Machine-Tractor Aggregate Diesel Engine with Electronic Positional Impact Regulator. Scientific Journal published by the Faculty of Mechanical Engineering, Vol. 46, 2018.

[12] Xia, S.Z, Zhou, M and Li, X.H. Dynamic response characteristics of the high-speed, powerful solenoid valve. Journal of Tsinghua University (Science and Technology), Vol. 42(2), pp258-261, 2002.

[13] Li, M.H. Research on Simulation for the Electronic Unit Pump Fuel Injection System of HXn5 Diesel Locomotive, Advanced Materials Research, Vol. 645, pp. 445-449, 2013.

[14]Zhang, S.L.; Zhao, Z.F.; Zhao, C.L.; Zhang, F.J. and Wang, S. Experimental study of the hydraulic, electronic unit injector in a hydraulic free piston engine. APPLIED ENERGY, Vol.179, pp.888-898

[15] Xuan-Thien, Tran, Milton, B., White, T. and Tordon, M. Modelling HEUI injector In MATLAB Simulink. Proceedings 2003 IEEE/ASME International Conference on Advanced Intelligent Mechatronics, 2003.

[16] Mulemane, A., Han, J., Lu, P., Yoon, S. et al., Modeling Dynamic Behavior of Diesel Fuel Injection Systems, SAE Technical Paper, 2004.

[17] Gudiño, L., Santiago, O., Yandun, V. and Ramiro, E. Modelación y simulación de los inyectores HEUI de un motor Cat C7. Modelación Y Simulación;Inyectores Heui De Un Motor Cat C7., 2018.

[18]Zhu, X., Limbu, S., Cung, K., De Ojeda, W. et al., HEUI Injector Modeling and ROI Experiments for High Injection Pressure of Diesel and Dimethyl Ether (DME), SAE Technical Paper 2016-01-0855, 2016.

[19] Coldren, D., Schuricht, S., Smith, R., Hydraulic Electronic Unit Injector with Rate Shaping Capability, SAE Technical Paper 2003-01-1384, 2003.

[20] Stockner, A.R., Flinn, M.A., and Camplin, F.A. Development of the HEUI Fuel System Integration of Design, Simulation, Test, and Manufacturing SAE Transactions. Journal of Engines, Vol. 102, pp. 311-326, 1993.

[21] Smoczyński, M. and Szydłowski, T. Technical University of Lodz Department of Mechanical Engineering Zeromskiego, Vol. 116, pp. 90-924.

[22] Glassey, S.F., Stockner, A.R. and Flinn, M.A. HEUI -A New Direction for Diesel Engine Fuel Systems. SAE Transactions. Journal of engines, Vol. 102. pp. 300-, 1993.

[23] Patent RU2101547 Drive and Valve Assembly for the hydraulic and electronically controlled injector. 10.01.1998
[24] Zhu, X., Limbu, S., Cung, K., De Ojeda, W. et al., HEUI Injector Modeling and ROI Experiments for High Injection Pressure of Diesel and Dimethyl Ether (DME), SAE Technical Paper 2016-01-0855, 2016.

[25] Jui,-Jung Liu, Ya-We, Lee, Shih-Yen, Yang, ChizChung, Cheng. Non-linear Identification and Analysis of a HEUI System. Proceedings of the 17th World Congress. The International Federation of Automatic Control. Seoul, Korea, July 6-11, 2008.

[26] Puente, E. Analisis Y Diagnostico Del Sistema De Cotrol Electronico De Inyeccion De Combustible Diesel HEUI CAT-3126/ INNOVA Research Journal, Vol.3, pp.145-150, 2018.

[27] Song, Jun, Huang, Jian-ping, Li, Xiao-lu, Li, Shuze and Huang, Zhen. Simulative Analysis for Drive Properties of High-Speed Solenoid Valve in Diesel Engines (School of Mechanical and Power Eng., Shanghai Jiao Tong Univ., Shanghai, 2000.

[28] Nestorović, D., Jovanović V.V., Manić, N.G.. Stojiljković, D.D. Engine and road tests of blends of biodiesel and diesel fuel. FME Transactions/ Volume 40, Issue 3, 2012, Pages 127-133.

[29] Rakić, S. Cvetić, M. Calculation of flow parameters inside the high pressure line of fuel injection system in diesel engines. FME Transactions Volume 36, Issue 3, 2008, Pages 113-117.

\section{ТЕОРИЈСКО И ЕКСПЕРИМЕНТАЛНО ПРОУЧАВАЊЕ ХИДРАУЛИЧКИ АКТИВИРАНЕ ИНЈЕКТОРСКЕ ПУМПЕ СА ЕЛЕКТРОНСКИ КОНТРОЛИСАНИМ ПРСТЕНАСТИМ ВЕНТИЛОМ}

Ф. Габдрафиков, М. Абраров, С. Шамукајев, И. Ајсуваков, Д. Харисов, У. Макхијанов, Д. Јукин

Релевантност овог истраживања представља одсуство карактеристика високих перформанси контролног система склопа вентила код инјекторске пумпе. Циљ истраживања је развијање модела за модернизовање инјекторске пумпе да би се повећале функционалне перформансе и развио контролни вентил. Главни метод истраживања проблема је процена утицаја параметара дизајна контролног вентила на квалитет рада пумпе. Аутори су развили метод за побољшање рада пумпе коришћењем прстенстог контролног вентила као и математички модел функционисања вентила код пумпе, што је омогућило креирање параметара који утичу на квалитет његовог функционисања. Резултати истраживања су показали ефикасност рада вентила код пумпе. Вентил има функцију силе и елемента за закључавање.

Одсуство енергетског елемента (опруге) може значајно да смањи запремину шупљине у унутрашњости вентила. Прстен функционише као механички множилац слободне ивице уграђен у њега са фактором множења $\pi$. Не постоји опруга, запремина пражњења се смањује а брзина рада пумпе се повећава. 